\begin{tabular}{|c|c|}
\hline $\begin{array}{l}\text { EXCELLENT } \\
\text { PUUBLISHERS }\end{array}$ & $\begin{array}{c}\text { International Journal of Current Research in } \\
\text { Biosciences and Plant Biology } \\
\text { ISSN: 2349-8080 (Online) } \bullet \text { Volume } 3 \bullet \text { Number } 7 \text { (July-2016) }\end{array}$ \\
\hline
\end{tabular}

\title{
The Gorilla Nesting Ecology of Kagwene Gorilla Sanctuary, North West Region, Cameroon
}

\author{
E. M. Melle*, A. F. Nkwatoh and H. M. Ngonpan \\ Department of Environmental Science, Faculty of Science, University of Buea, Cameroon \\ *Corresponding author.
}

\begin{tabular}{|c|c|}
\hline Abstract & Article Info \\
\hline \multirow{18}{*}{$\begin{array}{l}\text { Kagwene Gorilla Sanctuary provides a habitat for Gorilla gorilla diehli, one of the } \\
\text { worlds' most critically endangered sub-species. The objective of this study was to } \\
\text { explore some important areas of the nesting ecology of Gorillas such as vegetation } \\
\text { structure and architectural characteristics. This survey was accomplished by laying } 68 \\
\text { circular plots of } 35 \mathrm{~m} \text { radius each, with an interval distance of } 50 \mathrm{~m} \text { for elevations } \\
\text { between } 1500 \mathrm{~m}-2038 \mathrm{~m} \text { on a line transect. A track- based search of foraging paths and } \\
\text { knuckle-prints for fresh nest sites. Data was also recorded on the diameter at breast } \\
\text { height of the nesting trees about } 1.3 \mathrm{~m} \text { above the ground. Moreso, the tree branches used } \\
\text { for nesting were cut and analysed for fibre density. For the nests constructed on the } \\
\text { ground, thickness at different elevations was recorded. The recorded data on chect- } \\
\text { sheets was analysed by correlation and regression statistical models. For results, five } \\
\text { habitat types were established within which a total of } 525 \text { nests ( } 339 \text { Tree and } 186 \\
\text { ground) were found, } 44.2 \% \text { of which were in primary forests. The result of the study } \\
\text { recorded a significant positive correlation relationship between Tree diameter at breast } \\
\text { height (DBH) and nest height ( } \mathrm{r}=0.331, p=0.00) \text {. Also, a weak significant relationship } \\
\text { was observed between nest-thickness and elevation }(\mathrm{r}=0.028 \text {, } p=0.875) \text {. The plants } \\
\text { species from eight families (Guttiferae, Meliaceae, Acanthaceae, Zingiberaceae, } \\
\text { Caesalpinioideae, Rubiaceae, Meliaceae, and Commelinaceae) occurred in more than } \\
\text { one elevation accounting for abundant nesting materials. } 86.4 \% \text { of nesting trees had } \\
\text { fibre density between } 0.6-1.0 \text {, with mean fibre density }=0.82 \text {, which is indicative of } \\
\text { hard wood. Finally, this study has revealed that some ecological features like habitat } \\
\text { structure, vegetation type, DBH, and elevation gradients have impact on the Gorilla } \\
\text { nest-construction behavior. However, further studies should be carried out on tree crown } \\
\text { effect on nesting, the nutritional constituents of nesting material and the behavioural } \\
\text { ecology of gorillas. }\end{array}$} & $\begin{array}{l}\text { Accepted: } 14 \text { June } 2016 \\
\text { Available Online: 06 July } 2016\end{array}$ \\
\hline & Keywords \\
\hline & $\begin{array}{l}\text { Gorilla gorilla diehli } \\
\text { Endangered species }\end{array}$ \\
\hline & Kagwene Gorilla Sanctuary \\
\hline & Nesting ecology \\
\hline & \\
\hline & \\
\hline & \\
\hline & \\
\hline & \\
\hline & \\
\hline & \\
\hline & \\
\hline & \\
\hline & \\
\hline & \\
\hline & \\
\hline & \\
\hline
\end{tabular}

\section{Introduction}

The African rainforest contains an outstanding diversity and abundance of large mammals, which is unmatched in any other forest system of the world (Tutin and Vedder, 2001). Primates are important components in forest ecosystems, and their community makes up only about
$10 \%$ of the total mammalian biomass (White, 1994). Many of the African rainforest primates are ecological specialists occurring at low population densities, and they live in habitats that are increasingly threatened by human activities. Although the African rainforest occupies a smaller area, it supports a very diverse mammal community, including about 50 primate species 
(IUCN, 1996). Moreover, the loss of forest habitat is the key reason for primate species extinction (Oates et al., 2000).

The Cross River Gorilla (CRG) is known to be one of the world's 25 most endangered primates, according to the IUCN Primate Specialist Group (IUCN, 2013). This sub species is classified as one of Africa's most critically endangered species of primates, meaning it is considered to be facing an extremely high risk of extinction in the wild (IUCN, 2006). In the world, this sub species has been proven to occur only within the limited forest patches located along the Cameroon-Nigerian borders with a population of less than 300 individuals; and are found associated with hilly refuge sites on either side of the Cameroon-Nigeria border (Oates et al., 2008). A recent geographic and morphological analysis of skeletal specimens from the population of Cross River gorilla (Gorilla gorilla diehli) has proven that they are sufficiently distinct from other western gorillas to justify their being classified as a subspecies (Oates et al., 2003).

Although seasonality has not been taken into consideration, with respect to this study, seasonal nesting data, recorded over three years at the Kagwene Mountain, show that in the dry season $81.3 \%$ of all nests were constructed on the ground and only $18.7 \%$ were constructed on trees. Conversely, of nest sites recorded in the wettest months, only $30.6 \%$ were constructed on the ground and $69.4 \%$ were constructed in trees (Sunderland-Groves, 2008).

Nest construction in gorillas is thought to be influenced by different environmental factors such as climate, habitat structure, food availability, and the potential disturbance by sympatric large mammals (Tutin et al., 1995). As humans expand in number and their own range increases for farmland, pasture, roads and exploitation of timber, wild animals such as gorillas are restricted to shrink in population (Barnes, 2002). Although hunting was formerly a major threat to their survival, habitat loss and fragmentation are now assuming increasing importance. Before the gazettement of Kagwene highlands as a gorilla sanctuary, there was intense hunting of large and medium-sized mammals with the exception of gorillas. These have been affordable protection to their population over the years by a traditional law forbidding their hunting. Therefore, the most pressing threat to the gorilla population in this area is habitat loss since pastoral cattle herders utilise mountain slopes and have converted large areas of the forest to grassland (Sunderland-Groves et al., 2009).
Thus, this has warranted means of research and conservation to properly manage their already fragmented habitats.

Identifying and protecting trees used for nesting has been recommended as a practical approach to reduce the negative impacts of logging on great apes (Sanz et al., 2007). This is especially true, due to the fact that a minimum of only 200 weaned individuals are estimated to be surviving in the wild (Nicholas et al., 2010). However, there has been little focus on identifying gorilla nesting materials, and studies that assess plant selection for nest building in relation to plant availability in the forest are rare (Tutin et al., 1995; Rothman et al., 2006).

Investigating the architectural ability of Cross River gorillas in nest construction is of great importance because knowledge of plant species used for nesting can lead to designation of suitable habitats. Moreover, very few studies have been able to provide adequate information on vegetation used for nesting by gorillas in Kagwene Gorilla Sanctuary (KGS). If the habitat structure of this area is not well established and protected, it becomes a problem for this critically endangered great ape species; since they get exposed to further fragmentation via human activities such as cattle rearing. Furthermore, no study has been carried out in this area to determine fibre density of nesting trees, which will give a broader insight as to why some species could be used for nesting.

\section{Materials and methods}

\section{Location of study area}

Kagwene Gorilla Sanctuary (KGS) Cameroon is a $19.44 \mathrm{~km}^{2}$ protected area created in April 2008 (Wiseman et al., 2008). It lies on a mountainous terrain within the congo basin forest zone, occupying the highest altitude within cross-river gorilla distribution (De Vere et al., 2011). KGS is situated between South and North West Regions of Cameroon. It is located between $06^{\circ} 05^{\prime} 55^{\prime \prime}$ and $06^{\circ} 08^{\prime} 25^{\prime \prime}$ North and between $09^{\circ} 43^{\prime} 35^{\prime \prime}$ and $09^{\circ}$ 46' 35" East (Bergl et al., 2008) (Fig. 1). Kagwene mountains are of the Western highlands of Cameroon and form part of a chain of mountains from Bioko Plateau State, Nigeria, with altitudes over $2000 \mathrm{~m}$ above sea level (Funwi-Gabga et al., 2011). KGS is bounded to the northwest by Ngwo and Ekoh villages, to the southeast by Tchikpa and Kenshi, to the southwest by Alumfa and to northeast by Ayi and Amassi villages. 


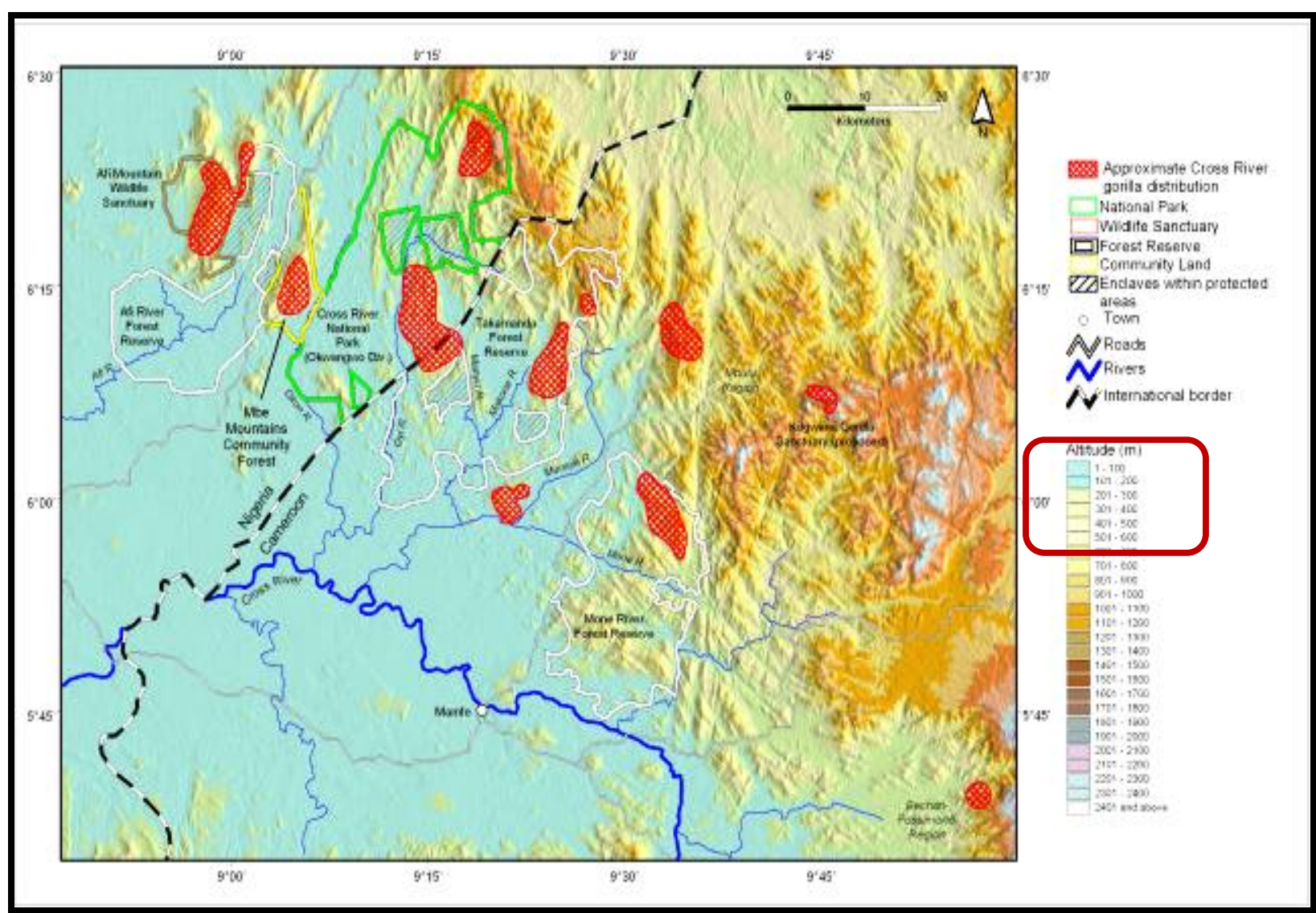

Fig. 1: The distribution of the Cross River Gorilla, Gorilla gorilla diehli in the study area (Source: IRSNB, 2007).

\section{Method}

The northern sector of the Kagwene Gorilla Sanctuary was purposively selected due to the fact that Gorillas are known to inhabit this section of the Sanctuary (De Vere et al., 2011). Meanwhile opportunistic sampling of fresh nest sites was carried out due to the sporadic nature of nest construction by gorillas in the wild. Nest sites occurring 30-50 $\mathrm{m}$ apart from each other were considered as separate (Morgan et al., 2006). Thus an average of six circular plots of $35 \mathrm{~m}$ radius at an average distance of $50 \mathrm{~m}$ apart were laid in each elevation within which dominant plants were identified and plant species used for nesting were counted. A trace based tracking of daily foraging paths was made to search the previous nights' nests (fresh nests) using gorilla feeding trails, knuckle prints or path, and smell of dung. Feeding trails comprised of the remains of food in situ, and indicated gorillas' patterns of movement. This method was employed for two reasons: to avoid habituation that could make the animals vulnerable to poachers and/or disease and, to avoid influencing their natural behaviour in the wild.Only night nests constructed by gorillas were considered for this study; reason being that, although day and night nests may be composed of similar materials (Lukas et al., 2003).

The frequencies of plant species at different altitudinal gradients and plant species used for nesting at those elevations, were established by counting plant species within the circular plots at nest sites. Plant species used as nesting materials were also counted to see which habitat is mostly preferred by gorillas for nest construction. Both the trees and plant materials used by the gorilla for nesting were identified using a combination of characters such as the general form of the tree (buttresses, roots systems, bark texture; slash colour, smell and exudates, leaf type and shape) as well as the flowers, and fruits of the trees. The use of field-oven made it possible to prepare unidentified plant specimens for identification at the Limbe Botanic garden herbarium. For all tree species used for nesting, diameter at breast height $(\mathrm{DBH})$ at $1.3 \mathrm{~m}$ above ground level from up slope, were measured using a DBH meter tape. The heights of the trees, as well as nest height above ground level were also estimated (average estimates of all field workers). The recording of this data collection was done on welldesigned rain-proof field eco-data sheets. 


\section{Results}

The habitant type for the nest construction by gorillas in the study site is given in Table 1.

Table 1. Habitat type for nest construction categories

\begin{tabular}{lll}
\hline Habitat type & Ground nest $(\%)$ & Tree nest (\%) \\
\hline Primary forest $(\mathrm{N}=298)$ & 12.6 & $44.2 \%$ \\
Montane forest $(\mathrm{N}=11)$ & 0 & 2.1 \\
Secondary forest & 16 & 19.4 \\
(N=186) & & \\
Light gap (N=18) & 2.6 & 0.8 \\
Grassland (N=11) & 2.1 & 0 \\
\hline
\end{tabular}

\section{Number of nests per site}

For this study, 68 fresh (1-2 days old) nest sites containing 525 individual nests of $\mathrm{CR}$ gorillas were recorded. Mean number of nests per nest site was 7.74, $(\mathrm{N}=68, \mathrm{SD}=2.7$, median $=8$, range 2-15) and the most frequent number of nests per site was $7(\mathrm{~N}=12)$ (Fig. 2 and Table 2).

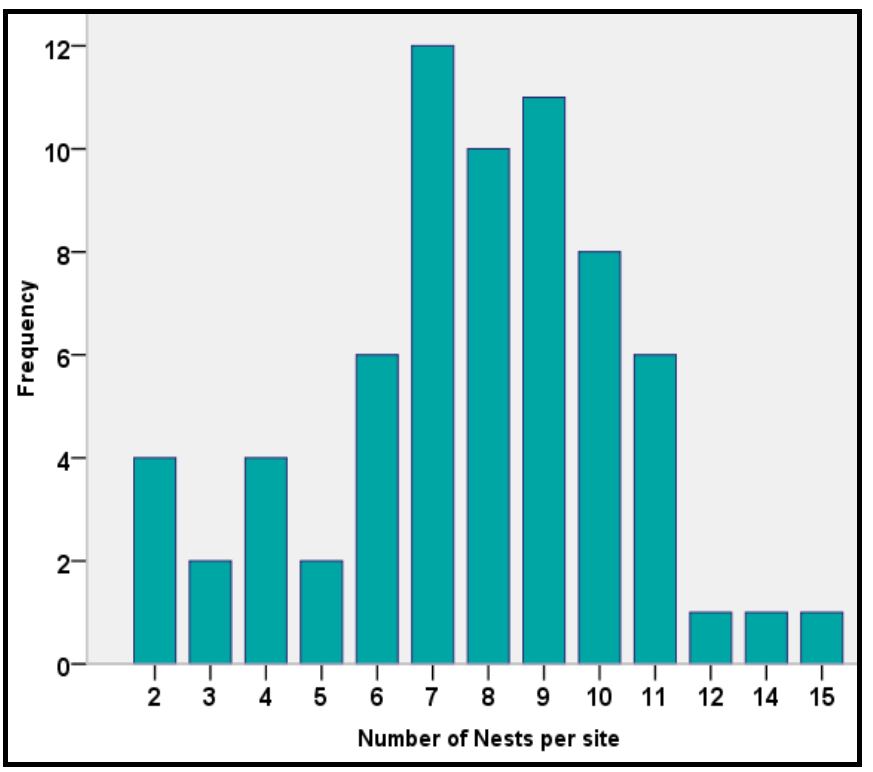

Fig. 2: Distribution of number of nests per gorilla nest site $(\mathrm{N}=68)$.

Table 2. Correlation of trees used for nesting and their fibre densities.

\begin{tabular}{lllll}
\hline \multicolumn{2}{c}{ Correlations } & & Tree species & Fibre density \\
\hline & \multirow{2}{*}{ Tree species } & Correlation Coeff. & 1.000 & $0.579^{* *}$ \\
& & Sig. (2-tailed) & - & 0.000 \\
\multirow{2}{*}{ Spearman's rho } & Fibre density & Correlation Coeff. & 336 & 330 \\
& & Sig. (2-tailed) & $-.579^{* *}$ & 1.000 \\
& & $\mathrm{~N}$ & 0.000 & - \\
& & 330 & 330 \\
\hline ** Correlation is significant at the 0.01 level (2-tailed).
\end{tabular}

\section{Diameter at breast height of trees with nests}

This studies show that CR gorillas at Kagwene prefer nesting on trees with DBH between 11 to $50 \mathrm{~cm}$, with 50 $\%$ of all nests on trees between DBH 11 and $20 \mathrm{~cm}$. The mean diameter at breast height $(\mathrm{DBH})$ of trees with nests was $38.03(n=339, \mathrm{SE}=1.4$, median=30.5 (Fig. 3).

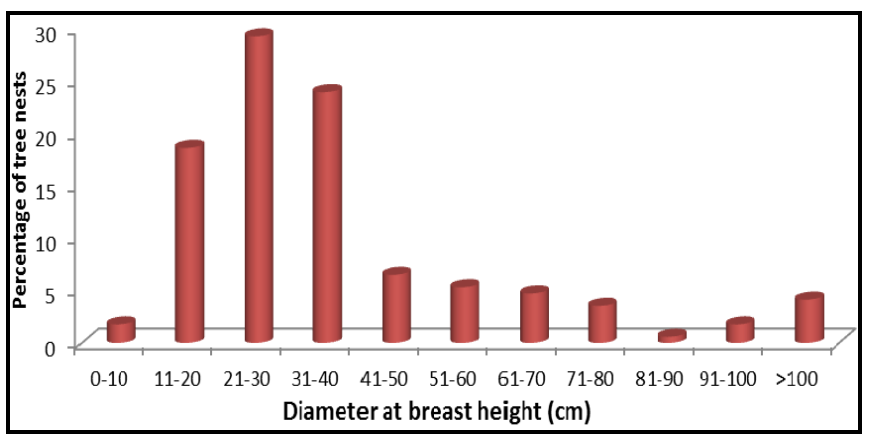

Fig. 3: Percentage of CRG nests at different DBH ranges at KGS.

\section{Relationship between trees DBH and nest height}

There is a significant relationship between nest height and tree DBH $(\mathrm{r}=0.331, p$-value $=0.00)$. This therefore implies that the larger the tree, the higher the nest from the ground (Table 3 ).

Table 3. Correlation of nest height and DBH of trees used for nesting.

\begin{tabular}{llll}
\hline & & $\begin{array}{l}\text { Tree } \\
\text { species }\end{array}$ & $\begin{array}{l}\text { Fibre } \\
\text { density }\end{array}$ \\
\hline $\begin{array}{l}\text { Tree } \\
\text { species }\end{array}$ & Correlation Coef. & 1 & $0.331(* *)$ \\
& Sig. (2-tailed) & - & 0.000 \\
& $\mathrm{~N}$ & 339 & 339 \\
\hline $\begin{array}{l}\text { Fibre } \\
\text { density }\end{array}$ & Correlation Coef. & $0.331(* *)$ & 1 \\
& Sig. (2-tailed) & 0.000 & - \\
& $\mathrm{N}$ & 339 & 339 \\
\hline
\end{tabular}

** Correlation is significant at the 0.01 level (2-tailed). 


\section{Relationship between nest thickness and elevation}

There exists a positive relationship between nest thickness and elevation ( $\mathrm{r}=0.028, p=0.875)$ (Fig 4).

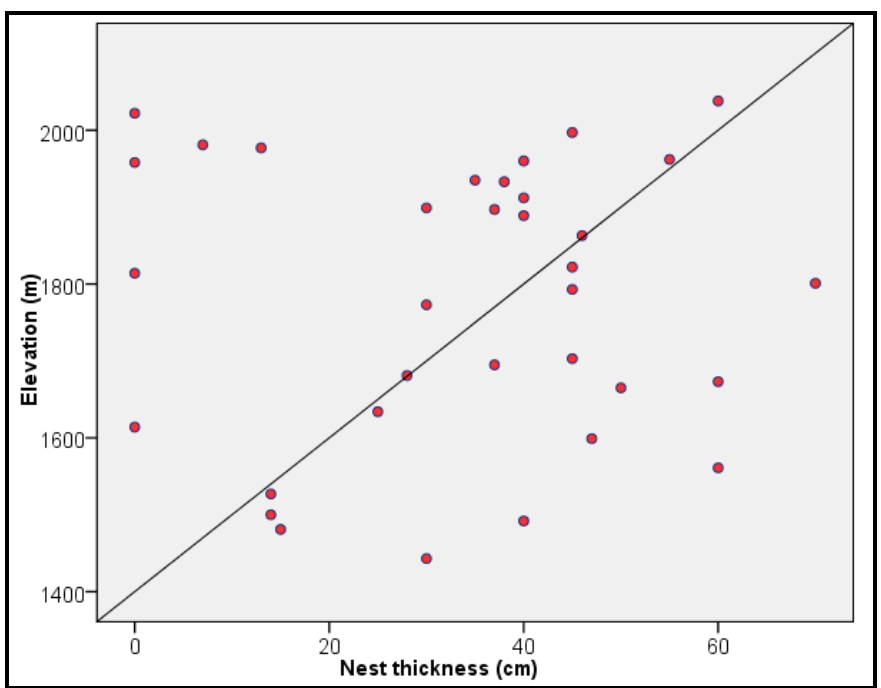

Fig. 4: Relationship between nest thickness and elevation at KGS.

\section{Habitats used for nesting}

Nest site distribution in the Kagwene Gorilla Sanctuary still occurs predominantly in the northern sector and within sanctuary boundaries than in other areas in the sanctuary, confirming the study ofDe Vere et al. (2011). This habitat preference could be due to the safety awareness, forest type, steepness and less disturbance from anthropogenic activities. Habitat strongly influences nest construction type since it is a determinant factor to what materials are made available for nesting. Due to the presence of tall and mature trees in primary forest and less undergrowth vegetation unlike the other habitat types, it is most probable that tree nesting is common in the later. This gorilla species preferably construct nest very often in the primary forest zone. The reason for this gorilla species consistent nest construction in the primary forest might also be related to the secured nature of this montane forest habitat, availability of material and even choice of nest type that they need to construct. Although gorillas at KGS nested in light gaps which tied with reports of Tutin et al. (1995), Mehlman and Doran (2002) and Rothman et al. (2006), western Lowland gorillas appear to select to a greater extent, habitats composed of light gaps; with open canopies, having a higher density of preferred nestbuilding materials. Furthermore, these findings found that grassland area does not typically provide ideal habitat for nesting, Bergl 2006 and De Vere et al.
(2011). More so, this gorilla species made use of only $2.1 \%$ of the total habitat for ground nesting, which happened to be grassland. From gorilla nest site distribution on the map, these gorillas nest beyond the protected area boundary.

\section{Correlation between DBH nesting trees and nest height}

From the results, a significant relationship exist between Tree DBH and nest height $(r=0.331, p$-value $=0.00)$. This therefore implies that cross river gorilla prefer constructing their nests on trees at breast height since their weight might not permit them to make very high climbs on trees as compared to other primate species like the guenones which are more arboreal because of their small size and lighter weight body morphology. This work supports the findings of Brugiere and Sakom (2001) where a significant relationship exists between tree DBH and height of gorilla nests.

\section{Nest thickness}

Given that there is decrease in temperature with higher altitudes, the case of nest thickness increasing with higher elevations could be associated to the fact that these gorillas make use of more material so as to insulate themselves and thus spend more night hours comfortably. Hence a weak but positive correlation existing between nest thickness and elevation $(\mathrm{R}=0.028)$. This ties with the work of Sanz et al. (2007).

\section{Nest diameter}

Similar to the previous studies carried out at KGS (Neba, 2011), the gorillas group studied during this study maintained their social group size of seven individuals throughout the study. This might be because gorillas form social groups, with a dominant male heading the group to all feeding sites, including protection and other related social responsibilities like groom, play, mating (IRSNB, 2007). In addition, gorillas show the most stable grouping patterns of all the great apes.

\section{Fibre density}

Considering the strength of nesting trees, results from this study revealed that up to $86.4 \%$ of nesting trees have a fibre density which is between 0.6 and up to 1.0, indicating that despite the animals comparatively large size and heavy weight, averagely $90-210 \mathrm{~kg}$; ( IUCN, 1996), the tree species are strong enough to carry such 
body weights. On the other hand, the fact that there exist a negative correlation between tree species and fibre density implies fibre density to some extent cannot be concluded as the only factor in terms of tree selection for nesting.

\section{Elevations at Kagwene Gorilla Sanctuary used for nesting}

Cross river gorillas (Gorilla gorilla diehli) at Kagwene Gorilla Sanctuary (KGS) nest predominantly at very high elevations (between $1500 \mathrm{~m}$ to $2038 \mathrm{~m}$ ) on steep slopes just like the western lowland gorillas. This is in accordance with Neba (2011) and Oates et al. (2007), who reported that CRG are commonly located in hilly and difficult terrains, sometimes measuring over 2,000 $\mathrm{m}$ in height. Also, De Vere et al. (2011) pointed out that gorillas at KGS nested at a maximum elevation of $2037 \mathrm{~m}$, as confirmed by this study where nests were constructed at elevation of $2038 \mathrm{~m}$. This equally ties with the study of Etiendem et al. (2013).

\section{Conclusion}

This survey has revealed the significant importance of some ecological factors influencing the cross river gorilla population distribution in this montane forest zone. The nesting ecological structure of gorilla is more on the ground than on the trees due the heavy body weight as compared to other primates species. In addition the nest construction behaviour and pattern revealed the involvement of some tree species like Zenkerella citrina (Caesalpinioideae), Garcinia smeathmannii, G. ovalifolia (Guttiferae) and Carapa grandifolia (Meliaceae). However, different habitat characteristics equally played a significant role in the nest construction and distribution. Majority of the nest were observed on the ground surface of the forested zone. The reason being that they more ground-dwelling than arboreal is due to their body weight and size. Furthermore, the availability of nesting material to a greater extent determined the choice of nest-type, distribution, tree-height, and elevation gradient. The presence of a safe atmosphere, nest construction material availability, and the richness of gorilla food in this sanctuary seem to have a tremendous positive effect to the population distribution.

\section{Recommendations}

In addition, a face to face observation was not made whether or not the various nests were built by an adult or juvenile gorilla to determine their skills. Hence a study on behavioural ecology of gorillas is recommended to clarify such doubts.

Cattle grazing within the sanctuary still possess a threat to the gorilla habitat. This is especially due to the fact that these gorillas nested equally in grassland during this study period. Therefore, persistent controls on hunting, prohibition of grazing at KGS (which could lead to uncontrolled burning) in combination with protection of habitat could allow the gorilla population to expand beyond the conserved area.

\section{Conflict of interest statement}

Authors declare that they have no conflict of interest.

\section{References}

Barnes, F.W., 2002. The bush meat boom and bust in West and Central Africa. Oryx.36, 236-242.

Bergl, R.A., 2006. Conservation biology of the Cross River gorilla (Gorilla gorilla diehli). $\mathrm{PhD}$. thesis. City University of New York, New York.

Brugiere, D., Sakom, D., 2001. Population density and nesting behaviour of lowland gorillas (Gorilla gorilla gorilla) in the Ngotto forest Central African Republic. J. Zool. (London). 255, 251-259.

De Vere, R.A., Warren, Y., Nicholas A., Mackenzie M.E., Higham, J., 2011. Nesting ecology of the Cross River gorilla at the Kagwene Gorilla Sanctuary Cameroon, with special reference to anthropogenic influence. Amer. J. Primatol. 73, 253-261.

Etiendem, N.D., 2013. Ecological and anthropogenic factors of Cross River gorilla (Gorilla gorilla diehli) survival at Mawambi Hills, southwest Cameroon. PhD thesis.Vrije Universiteit Brussel, Belgium.

Funwi-Gabga, N., Mateu, J., 2011.Understanding the nesting special behavior of gorillas in Kagwene Sanctuary Cameroon. Stochastic Environ. Res. Risk Assess. 26(6), 793-811.

IRSNB, 2007. Gorilla gorilla diehli, Status Report. The World Atlas of Great Apes and their conservation. Retrieved March, 2015 from http:www.naturalsciences.be/.../ Status_report_\%20CrossRiverGorilla_IRSNB

IUCN, 1996. African Primates: Status Survey and Conservation Action Plan. Revised Edn. IUCN, Gland, Switzerland. 88p.

IUCN, 2006. 2006 IUCN Red List of Threatened Species. www.iucnredlist.org

IUCN, 2013. Red List of Threatened Species 2013. Retrieved March 6, 2014 from http://www.iucnredlist.org.

Lukas, K.E., Stoinski, T.S., Burks, K., Snyder, R., Bexell, S., Maple, T.L., 2003. Nest building in captive Gorilla gorilla gorilla. Inter. J. Primatol. 24(1), 103-120.

Mehlman, P.T., Doran, D.M., 2002. Influencing western 
gorilla nest construction at Mondika Research Centre. Int. J. Primatol. 23, 1257-1285.

Morgan, D., Sanz, C., Robert, J.O., Strindberg, S., 2006. Ape abundance and habitat use in the Goualougo Triangle, Republic of Congo. Int. J. Primatol. 27(1), 147-175.

Neba, F., 2011. Spatial Point Pattern Analysis of Gorilla Nest Sites in the Kagwene Sanctuary, Cameroon. Master's thesis, UniversitatJaume I (UJI) Castellon, Spain.

Nicholas, A., Warren, Y., Bila, S., Ekinde, A., Ikfuingei, R., Tampie, R., 2010. Successes in community-based monitoring of Cross River Gorillas (Gorilla gorilla diehli) in Cameroon. Takamanda-Mone Landscape Project. Afr. Primates. 7(1), 55-60.

Oates, J.F., Abedi-Lartey, M., McGraw, S., Struhsacker, T.T., Whitesides, G.H., 2000. Extinction of a West African red colobus monkey. Conserv. Biol. 14, 1526-1532.

Oates, J. F., McFarland, K.L., Groves, J.L., Bergl, R.A., Linder, J.M., Disotell, T.R., 2003. The Cross River gorilla: Natural history and status of a neglected and critically endangered subspecies. In: Gorilla Biology: A Multidisciplinary Perspective (Eds: Taylor, A.B., Goldsmith, M.L.). Cambridge University Press. pp. 472493.

Oates, J.F., Bergl, R.A., Sunderland-Groves, J., Dunn, A., 2008. Gorilla gorilla ssp. diehli. In: IUCN 2010. IUCN Red List of Threatened Species.

Rothman, J.M., Pell, A.N., Dierenfeld, E.S., Mccann, C.M., 2006. Plant choice in the construction of night nests by gorillas in the Bwindi Impenetrable National Park, Uganda. Am. J. Primatol. 68, 361-368.

Sanz, C., Morgan, D., Strindberg, S., Onononga, J.R. (2007). Distinguishing between the nests of sympatric chimpanzees and gorillas. J. Appl. Ecol. 44, 263-272.

Sunderland-Groves, J.L., Maisels, F., Ekinde, A., 2003. Surveys of the Cross River gorilla and chimpanzee populations in Takamanda Forest Reserve, Cameroon. In: Takamanda: The Biodiversity of an African Rainforest (Eds.: Comiskey, J. A., Sunderland, T. C. H., SunderlandGroves, J. L.). Smithsonian Institution, Washington, D.C.

Sunderland-Groves, J.L., 2008. Population, distribution and conservation status of the cross river gorilla (Gorilla gorilla diehli) in Cameroon. Retrieved from http:// www.ellioti.org/JLSunderland-GrovesMPhil2008.pdf

Tutin, E.G., Parnell, R.J., White, L.J.T., Fernandez, M., 1995. Nest building by lowland gorillas in the Lop'e Reserve, Gabon: Environmental influences and implications for censusing. Int. J. Primatol. 16(1), 53-76.

Tutin, C.E.G., Vedder, A., 2001. Gorilla conservation and research in Central Africa: a diversity of approaches and problems. African Rain Forest Ecology and Conservation (Eds.: Weber, W., White, L.J.T., Vedder, A., NaughtonTreves, L.). Yale University Press, New Haven. pp.429448.

White, L.J.T., 1994. Biomass of rain forest in the Lope Reserve Garbon. Anim. J. Ecol. 66, 499-512.

\section{How to cite this article:}

Melle, E. M., Nkwatoh, A. F., Ngonpan, H. M., 2016. The gorilla nesting ecology of Kagwene Gorilla Sanctuary, North West Region, Cameroon. Int. J. Curr. Res. Biosci. Plant Biol. 3(7), 40-46. doi: http://dx.doi.org/10.20546/ijcrbp.2016.307.007 